omitted. Those familiar with this publication need no further recommendation; others who do not know what a gold mine of valuable information it is should make a point of looking into it for themselves. In these days of rapid advances, it is surprising to find that the Council of the American Medical Association have managed to include in this edition information about such new preparations as, for example, Methylprednisolone, Influenza Virus Vaccine (Asian strain) and Chlorambucil. The book provides an authoritative manual of modern therapeutics for as little as zos.

\section{A POCKET BOOK OF PROPRIETARY DRUGS}

By A. G. Cruikshank and C. Stewart. Pp. 236. Edinburgh: E. \& S. Livingstone Ltd. Ios. $6 \mathrm{~d}$. (Interleaved Edition, I4s.).

This is a useful little book which gives a description of about $\mathrm{I}, 500$ proprietary preparations, with the indications (presumably those listed by the manufacturers), dosage and details of packs. There is a real need for this type of reference book and this one is a convenient size. Some omissions have been noted, e.g. oral Florinef (Squibb). Percorten is said to be the same as desoxycortone acetate and the trimethylacetate (they are not equivalent). Inversine is available in two strengths $(2.5 \mathrm{mg}$. and ro mg.). Only Novo Lente is mentioned as a representative preparation of insulin zinc suspension and no explanation of the lengths of action of the three forms is given. It is not true to say that in the dosages of neomercazole so far employed no toxic or other side-effects have been noted: the makers certainly do not say this.

\section{BIOCHEMISTRY IN RELATION TO MEDICINE}

By C. W. Carter, R. V. Coxon, D. S. Parsons and R. H. S. Thompson. Pp. 628. 3rd Edn. London: Longmans, Green \& Co. 50 s.

Dr. Coxon and Dr. Parsons have joined the two original authors of this standard textbook, which has been extensively revised since the last edition appeared in 1953 . The practical exercises of previous editions have been omitted. New chapters are included dealing with the digestive secretions, and the mechanisms of intestinal absorption. Endocrinology and renal function receive more attention than before. There is a very comprehensive bibliography as well as a good index. This is an excellent, authoritative work, which can be highly recommended to clinicians needing an up-to-date account of the subject. It is well printed and not expensive.

\section{PANMINERVA MEDICA}

The Journal of the Italian Medical Association English Language Edition. Vol. I, No. I (May
1959). Torino: Edizioni Minerva Medica. Annual subscription $£_{3}$ ros.

This new journal is to appear monthly. It is very well produced and printed on a big page of paper of good quality. The English is uneven, though that of most of the articles is excellent, and on the whole the references to English papers (so often full of errors and misprints in continental journals) seem to have been carefully checked. The illustrations are well reproduced. There is a wide selection of papers, many of considerable interest, together with a section devoted to conference reports and news of current actixities in Italy. This new journal will receive a warm welcome in this country and if the publishers can maintain the standard of the first number it will be read with great interest.

\section{PSYCHOLOGY, THE NURSE AND THE PATIENT}

By Doris M. Oduum, M.A., M.R.C.S., L.R.C.P., D.P.M. Third Edition. Pp. viii + 196. London: Iliffe \& Sons Ltd. I959. I 5 s. net.

This book is addressed primarily to those who have taken up or are about to enter the nursing profession, but it should prove equally valuable to all who are directly or indirectly concerned with the care and treatment of the sick, that is to say, with every branch of a hospital staff, with almoners, health visitors and other social workers, and, last but by no means least, with members of the medical profession. The message which the author has to convey to her readers is well summarized in one of the introductory sentences on the very first page:

'Nurses in their daily work are dealing with people; with their patients, with their colleagues, doctors and surgeons, their superior officers and their juniors, and a multiplicity of other human beings. If they are going to understand the people they are dealing with it is necessary to have some idea of the way in which the human mind works; of the manner in which folk feel and think and are likely to behave.'

At the outset of our review we take the opportunity to congratulate Dr. Odlum on her admirable presentation of this important and difficult subject. She puts into a nutshell the essence of what is meant by nursing as a vocation. Her description of Inborn Mental Factors is an admirable summary of the latest teaching of experts in psychology, expressed in clear and simple language that can be easily understood by anyone who has had a reasonable general education. Chapter VI especially impressed us as a lucid account of the subconscious mind, in which the reader is given the essential truths about this subject without indulgence in the exaggerated jargon so frequently employed by so many modern psychiatrists. All the chapters, however, are good, and all are eminently practical.

The volume as a whole is easy to read; not the 
least of its attractions is its literary style, the fruit doubtless of its author's original training in the classics, in which she took honours at our premier university. We strongly commend her book to all who love clear, sound thinking and scholarly writing.

\section{THERAPEUTIC ELECTRICITY AND ULTRAVIOLET RADIATION}

Edited by Sidney Licht, M.D. First edition. Pp. 343, with a preface and index. Published by Elizabeth Licht in 1959. \$10 (in this country £3 $17 \mathrm{~s}$.).

This is the fourth volume of a series by the editor, called Physical Medicine Library, which when complete will exhaustively cover the whole field of physical medicine. The main appeal, therefore, will be as a reference work for the physical medicine specialist rather than a textbook for the student, who in any event could ill afford the price. It follows the same pattern as the previous volumes in that the ground covered is divided between several contributors-nine in this case-some of whom take a long time to say what they have to say and do so with some overlapping of information. The historical section and bibliographies are unusually long. The authors of the section of physiological effects of ultra-violet radiation fail in their intention to relate clearly the observed effects in man and mammals to those seen in the biological laboratory on protozoa and plants. The chapters on clinical electric stimulation and iontophoresis and instrumentation for and clinical uses of ultra-violet radiation are the best in their respective sections. The table on page 201 needs a mathematical alteration at the top of column three, headed 'Millimicron.' On page I I I it is not made clear that fibrillation potentials are detected at electromyographic examination three or four days after denervation is complete. The inclusion of a chapter on electro-sleep therapy is somewhat sensational and of little interest to any but the psychiatrist. The claims made for the work on the inside of the paper cover are extravagant and intended largely, no doubt, as sales talk.

\section{BREAST CANCER}

The Second Biennial Louisiana Cancer Conference, New Orleans, January 22-23, 1958

Edited by Albert Segaloff, M.D. Pp. 257, illustrated. St. Louis: The C. V. Mosby Co. Distributed in Great Britain by Henry Kimpton, London. 1958. £i 17s. 6d.

'This volume records the formal papers and the panel discussions of the conference. The papers are grouped under the headings of basic biology, definitive treatment and hormonal therapy. Worthy of special note are the papers of Dr. Ian Macdonald on clinical evidence of biological variability in mammary carcinoma, of Dr. 'Thal and of Dr. Urban on the extended radical operation, and of Dr. Haagensen on criteria of operability. The panel $\mathbb{\mathbb { D }}$ discussions are reported freely and informally with such phrases as "even if I miss my plane and have $\stackrel{-}{\Rightarrow}$ to walk to Tucson I have to take a crack at that,' and as a result are valuable in elucidating the $\overline{0}$ opinions of the participants. The volume as a whole, and in particular the papers of Dr. Macdonald and of Dr. Haagensen, reflect the present mood of questioning in the management of breast cancer: How important is early operation? Are certain क cases, though operable, best treated by other means than operation? If so, which cases, and how should they be treated?

\section{INSULIN TREATMEN T IN PSYCHIATRY}

Edited by M. Rinkel and H. E. Himwich. Pp. XXIX + 386. New York: Philosophical Library. I959. 39s.

This book deserves close study by all psy- ì chiatrists. It includes the papers read and ensuing of discussions at the International Conference held at the New York Academy of Medicine in 1958, during which all aspects of insulin treatment in psychiatry were covered.

With the advent of electroplexy, neuro-surgical procedures and certain tranquillizers since Sakel's introduction of insulin coma treatment over 30 years ago it was time to take stock of their relatike benefits in view of the decline in use of the latte⿳亠二口犬 This volume certainly affords refreshing and in? structive reading. It is divided into three parts: historical contributions, physiochemical research and clinical research. An appendix contains a translation of Sakel's address at the University of Vienna the previous year at the 30-year celebration of his discovery.

Although much of the content concerns insulin coma treatment, due attention is paid to modified insulin therapy and the possible or actual relative advantages of dual treatments, such as I.C.T. and E.C.T. or I.C.T. and tranquillizers. Whilst it may be argued that chlorpromazine or phenothiazine $\dot{0}$ derivatives are of definite therapeutic value, it is 3 . emphasized that insulin comas still have, or should $\delta$ have, a place in the treatment of certain schizo- 3 phrenics, but that particular attention should be paid to Sakel's original instructions on technique. This book and the conference which led to its pub- $\rightarrow$ lication could give rise to second thoughts in the few psychiatric hospitals in this country where insulin $N$ treatment units no longer function.

\section{A MANUAL OF PSYCHIATRY}

By K. R. Stallworthy. Fourth edition. Pp. 365. New Zealand: N. M. Peryer Ltd. 1959. 30s. net.

'This is a carefully planned and practical book ${ }_{7}^{+}$ containing an outline of normal and abnormal psychology followed by basic psychiatric medicine $\overrightarrow{\mathbb{D}}$ 